Modern Asian Studies 53, 3 (2019) pp. 943-977. (C) Cambridge University Press 2018. This is an Open Access article, distributed under the terms of the Creative Commons Attribution licence (http://creativecommons.org/licenses/by/4.o/), which permits unrestricted re-use, distribution, and reproduction in any medium, provided the original work is properly cited.

doi:10.1017/Soo26749X1700o634

\title{
Faraway Siblings, So Close: Ephemeral conviviality across the Wakhan divide*
}

\author{
TILL MOSTOWLANSKY
}

\author{
The Graduate Institute, Geneva \\ Email: till.mostowlansky@graduateinstitute.ch
}

\begin{abstract}
In this article, I set out to explore the possibility of a shared life between two places in the highlands of Pakistan and Tajikistan-a region dissected by Afghanistan's narrow Wakhan corridor, by present-day nation-state boundaries, by historical divisions between Central and South Asia, and by a former Cold War frontier. Moving away from a take on conviviality as specifically tied to urban spaces and face-to-face encounters, I attempt to trace the processes that determine the coming and going of shared modes of being. In doing so, I first situate the two places-Karimabad and Khorog-in their respective post-Cold War borderlands and point to their historically ambivalent status as 'marginal' places at the frontier, culturally diverse 'hubs', and sites of globalization. Then I analyse the historical build-up_-material and ideological—that led to the establishment of specific forms of connection and disconnection between the two places. In the last part of the article, I discuss how people in and from Karimabad and Khorog seek out opportunities to attain shared instances of common sociality, which often remain ephemeral and subject to regimes of power. Finally, I argue that the
\end{abstract}

* This article is based on repeated fieldwork stays in Tajikistan from 2008 to 2013 , and in Pakistan from 2012 to 2015. All interlocutors have been anonymized, with pseudonyms used in place of their real names. My heartfelt thanks go to them, and to Brook Bolander, Brian Donahoe, Magnus Marsden, Madeleine Reeves, and the four anonymous reviewers for their valuable feedback. I would furthermore like to express my gratitude to Daniel Beben for important insights regarding Nasir-i Khusraw. For comments on an earlier version of this article, I am also deeply indebted to the members of the Religion \& Globalization cluster at the Asia Research Institute, National University of Singapore, as well as to the participants of the workshop 'Conviviality Beyond the Urban Centre: Theorizing the "Marginal Hub"' at the 2016 InterAsian Connections V conference in Seoul. I would also like to thank the Hong Kong Institute for the Humanities and Social Sciences, The University of Hong Kong, for support throughout the writing process and the Swiss National Science Foundation (PZooP1_174163) for making this open access publication possible. 
cases of these two 'marginal hubs' highlight the importance of looking beyond the conventional 'imperial centre' when debating the dynamics that lead people to desire, create, and abandon ties across difference.

\section{Introduction}

Much of the literature on conviviality is based on two central assumptions. First, a number of authors have observed that living together across difference is a typical feature of urban spaces. In this respect, many studies have examined social encounters in past and present cities from southern Europe to South Africa and from Great Britain to Australia. Second, within this framework of shared urban lives, conviviality remains conceptually tied to ideas of proximity, density, continuity, and, sometimes, as Paul Gilroy notes, to 'the realization of a more worthwhile liberalism'. ${ }^{1}$ Yet how far do these assumptions take us in understanding difference in places beyond the pre-defined urban centre? What role do face-to-face encounters play in a world marked by both the use of translocal resources and technologies and the political form of the nation state? And what does it mean to think of conviviality more generally as, in Magnus Marsden's words, 'the ways in which life in culturally complex settings generates indeterminate modes of being that valorise the ability of people to forge relations, ties, and to join in practices across boundaries'? ${ }^{2}$

In this article, I examine these questions using the example of two places-one in Pakistan and the other in Tajikistan-and their

${ }^{1}$ P. Gilroy, After Empire: Melancholia or Convivial Culture?, Routledge, London, 2004, p. 162. See also A. Amin, Land of Strangers, Polity Press, Cambridge, 2012. A. Bell, 'Decolonizing Conviviality and Becoming Ordinary: Cross-Cultural Face-To-Face Encounters in Aotearoa, New Zealand' Ethnic and Racial Studies 39(7), 2016, pp. $1170-$ 1186 . I. Brudvig, Conviviality in Bellville: An Ethnography of Space, Place, Mobility and Being in Urban South Africa, Langaa, Bamenda, 2014. U. Freitag, 'Cosmopolitanism and Conviviality? Some Conceptual Considerations Concerning the Late Ottoman Empire' European Journal of Cultural Studies 17(4), 2014, pp. 375-391. P. Gilroy, Postcolonial Melancholia, Columbia University Press, New York, 2005. J. Overing and A. Passes, 'Preface' in The Anthropology of Love and Anger: The Aesthetics of Conviviality in Native Amazonia, J. Overing and A. Passes (eds.), Routledge, London, 2000. B. Padilla, J. Azevedo, and A. Olmos-Alcaraz, 'Superdiversity and Conviviality: Exploring Frameworks for Doing Ethnography in Southern European Intercultural Cities' Ethnic and Racial Studies 38(4), 2015, pp. 621-635. A. Wise and S. Velayutham, 'Conviviality in Everyday Multiculturalism: Some Brief Comparisons between Singapore and Sydney' European Journal of Cultural Studies 17(4), 2014, pp. 406-430.

${ }^{2}$ M. Marsden, Trading Worlds: Afghan Merchants Across Modern Frontiers, Oxford University Press, Oxford, 2016, p. 290. 


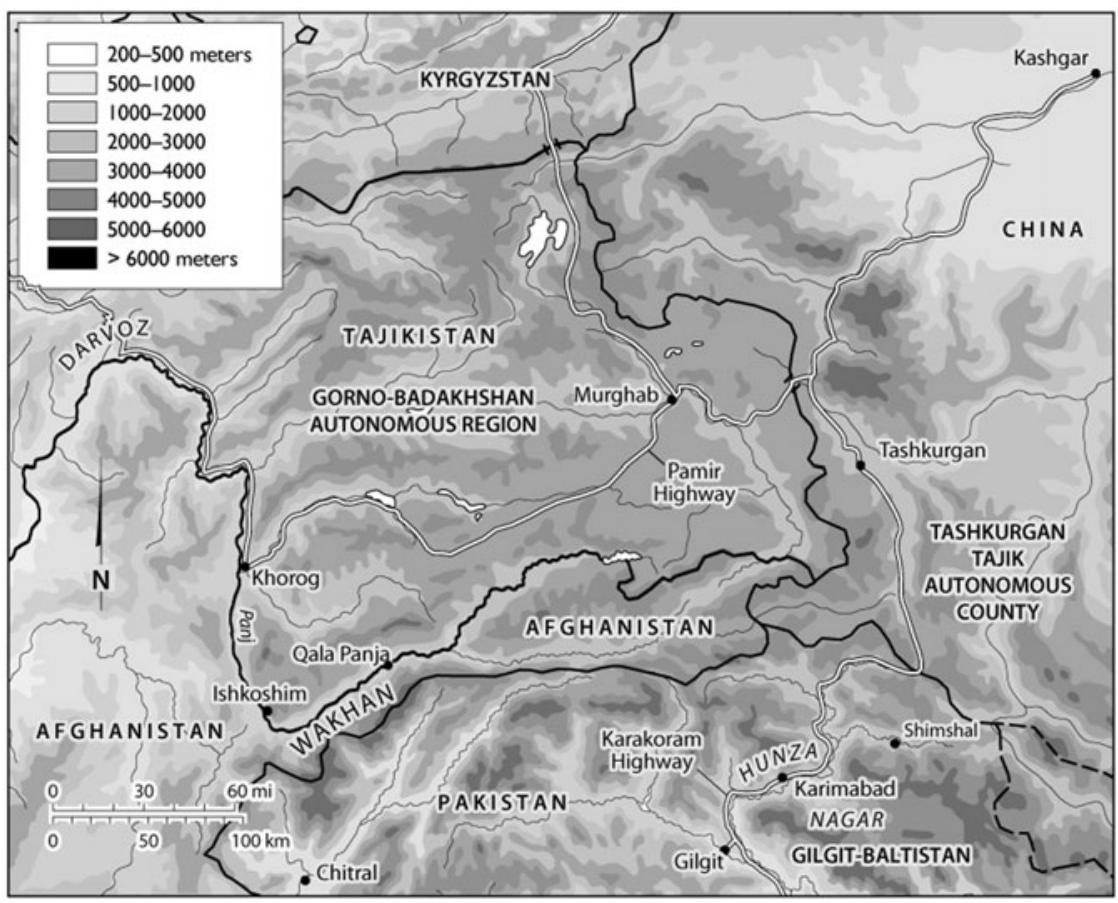

Figure 1: The borderlands of Afghanistan, China, Pakistan, and Tajikistan.

inhabitants' historically complex and discontinuous relations with one another. Both Karimabad in Pakistan and Khorog in Tajikistan are located at the frontier of Central and South Asia (see Figure 1), which has long been marked by processes of separation in the course of colonial, Cold War, and post-Cold War history. ${ }^{3}$ Starting with the delineation of the Afghan Wakhan corridor at the end of the nineteenth century-buffering the Russian and British empiresfollowed by the Soviet militarization of the border and hesitant attempts at post-Cold War integration, cross-border connectivity in the borderlands of Afghanistan, China, Pakistan, and Tajikistan has remained tied to specific moments and locales in time and space. As

${ }^{3}$ See S. Chari and K. Verdery, 'Thinking Between the Posts: Postcolonialism, Postsocialism, and Ethnography after the Cold War' Comparative Studies in Society and History 51 (1), 2009, pp. 6-34. H. Kwon, The Other Cold War, Columbia University Press, New York, 2010. M. Marsden and B. D. Hopkins, Fragments of the Afghan Frontier, Hurst, London, 201 1. T. Mostowlansky, 'Building Bridges across the Oxus: Language, Development and Globalization at the Tajik-Afghan Frontier', International Journal of the Sociology of Language 247, 2017. 
a result, these borderlands have predominantly been viewed either through the eyes of the respective nation states that dissect the area or in light of transregional integration between Central Asia, South Asia, and China. ${ }^{4}$ The exploration of the possibility of shared lives across the frontier, or the lack thereof, has been largely neglected. ${ }^{5}$

In the course of fieldwork I have conducted since 2008, I have encountered many people in the borderlands of Pakistan and Tajikistan for whom this state of disconnection is simply part of their everyday lives. To think, act, and travel across the border is not a frequent occurrence and requires conscious effort. Nevertheless, many of these same people also express an underlying sense that they are part of a broader common region through which their ancestors used to travel relatively freely, and that they share significant historical, cultural, and religious connections with other people in the broader region. Ideas of conviviality, and their infrequent materialization, remain under the surface, hidden but ready to be activated. For instance, after a bloody military intervention by Tajikistan's government in Khorog in 2012 , angry young men recalled their genealogical ties to territories and people in the neighbouring borderlands outside the Tajik nation state. While not explicitly linked to an alternate form of statehood, this remembrance of a common past projected bygone forms of living together into the future. Similarly, during my research in Karimabad, elderly people told me that they have always had to defend themselves against unjustified suspicions that they wanted to build a separate, cross-border state in the region.

\footnotetext{
${ }^{4}$ For a detailed overview of existing studies on the borderlands, see H. Kreutzmann, Pamirian Crossroads: Kirgiz and Wakhi of High Asia, Harrassowitz, Wiesbaden, 2015. For broader takes on transregional integration, see M. Laruelle, S. Peyrouse, J. Huchet, and B. Balci (eds.), China and India in Central Asia: A New 'Great Game'?, Palgrave, New York, 2010. M. Laruelle and S. Peyrouse (eds.), Mapping Central Asia: Indian Perceptions and Strategies. Ashgate, Farnham and Burlington, 2011.

${ }^{5}$ Exceptions focusing on the broader region include Kreutzmann, Pamirian Crossroads. S. Levi-Sanchez, The Afghan-Central Asia Borderland: The State and Local Leaders, Routledge, London and New York, 2017. E. Manetta, 'Journey into Paradise: Tajik Representations of Afghan Badakhshan' Central Asian Survey 30(4), 2011, pp. 371387. M. Marsden, 'Muslim Cosmopolitans? Transnational Life in Northern Pakistan' The Journal of Asian Studies 67(1), 2008, pp. 21 3-247. A. Remtilla, 'Re-Producing Social Relations: Political and Economic Change and Islam in Post-Soviet Tajik Ishkashim', PhD diss., University of Manchester, 2012. A. Rippa, 'Across the Khunjerab Pass: A Rhizomatic Ethnography along the Karakoram Highway, between Xinjiang (China) and Pakistan', PhD diss., University of Aberdeen, 2015. J. Steinberg, Isma 'ili Modern: Globalization and Identity in a Muslim Community, University of North Carolina Press, Chapel Hill, 2011.
} 
Such accusations, not to mention more casual cross-border musings, feed on the fact that people in Karimabad and Khorog, as well as in many other places in the borderlands of Afghanistan, China, Pakistan, and Tajikistan, are Nizari Ismaili Muslims whose transnational institutions are headed by their $49^{\text {th }}$ Imam, Prince Shah Karim Al Hussaini, the Aga Khan IV. As I will discuss later in this article, being part of the transnational Ismaili community is an important factor when people reach out beyond the boundaries of the nation state. However, as I will also argue, what it means to be Ismaili remains contested. Local identity has not simply dissolved into an abstract transnational form, but continues to be bound to places in this borderland area that-located at the fringes of empires and nation states-has never attained a common name.

People in Karimabad and Khorog are keenly aware of their positioning at this historically and geopolitically salient, yet marginalized, crossroads. As I will show in the following sections, they not only aptly navigate the different scales that emerge within this constellation, but also participate in the making of such scales. In this respect, Willem van Schendel's notion of 'Zomia' as a possible alternative geopolitical entity comprising the border zones in the highlands of Southeast Asia ${ }^{6}$ is particularly evocative, as is Anna Tsing's emphasis on the importance of local people's involvement in 'scale-making projects" that are embedded in different power relations. ${ }^{8}$ I suggest that my interlocutors themselves were in the business of 'scale-making', projecting a 'Zomia' of past interaction

\footnotetext{
${ }^{6}$ W. van Schendel, 'Geographies of Knowing, Geographies of Ignorance: Jumping Scale in Southeast Asia' Environment and Planning D: Society and Space 20, 2002, pp. 647668. James Scott's use of van Schendel's 'Zomia' has attained particular prominence over the past couple of years (see J. C. Scott, The Art of Not Being Governed: An Anarchist History of Upland Southeast Asia, Stanford University Press, Stanford, 20og). In this article, I will not follow Scott, whose approach is highly specific to Southeast Asia and focuses on 'state evasion', but van Schendel's conceptualization of 'Zomia', which reaches out into the highlands of Central Asia in the form of the so-called Zomia+ (see J. Michaud, 'Editorial: Zomia and Beyond' Journal of Global History 5(2), 2010, pp. 187-2 14). See also Marsden's 'Muslim Cosmopolitans', which looks at interactions between people from Chitral (Pakistan), Afghanistan, and Tajikistan precisely from this perspective.

${ }^{7}$ A. L. Tsing, Friction: An Ethnography of Global Connection, Princeton University Press, Princeton and Oxford, 2005, p. 57.

${ }^{8}$ See N. Brenner, 'Between Fixity and Motion: Accumulation, Territorial Organization and the Historical Geography of Spatial Scales' Environment and Planning D: Society and Space 16, 1998, pp. 459-481. N. Brenner, 'The Urban Question as a Scale Question: Reflections on Henri Lefebvre, Urban Theory and the Politics of Scale' International Journal of Urban and Regional Research 24(2), 2000, pp. 361-378.
} 
into a desirable future. On the one hand, this emphasizes the need to engage with the temporal dimensions of such projects, both in the past and in the future, as 'cultural facts' that are of relevance for an inquiry into the present. ${ }^{9}$ On the other hand, it also challenges the usefulness of standard temporal categories and periodizations that posit an a priori distinction between places on the assumption that the weights of colonial, socialist, post-colonial, and post-socialist pasts have inexorably separated them. ${ }^{10}$

Such reasoning is not only of relevance to the ways we look at borderlands and the people who inhabit them; it also challenges assumptions about which places are central and which are marginal within these spaces and how they are connected to or detached from the world beyond. ${ }^{11}$ For instance, in the framework of this article, I define Karimabad and Khorog as 'marginal hubs', thereby indicating that their status is ambivalent and relational. Thus, the question of who renders them both central and marginal from different vantage points and at different points in time lies at the heart of the matter. Charles Wheeler discusses the oscillation between centrality and marginality on the example of the interdependency of piracy and smuggling and the emergence and decline of political formations in the history of Vietnam. ${ }^{12}$ In this respect, the 'marginal centre' is

${ }^{9}$ A. Appadurai, The Future as Cultural Fact: Essays on the Global Condition, Verso, London and New York, 2013.

${ }^{10}$ See D. Owen Hughes, 'Introduction' in Time: Histories and Ethnologies, D. Owen Hughes and T. R. Trautmann (eds.), The University of Michigan Press, Ann Arbor, 1995, pp. 1-18. Owen Hughes advocates a careful and nuanced treatment of the relationship between historiography and historical time. For studies critically questioning particular periodizations in Central Asia and Pakistan, see, for example, J. Beyer, The Force of Custom: Law and Ordering of Everyday Life in Kyrgyzstan, University of Pittsburgh Press, Pittsburgh, 2016. D. Ibañez-Tirado, "How Can I Be Post-Soviet if I Was Never Soviet?": Rethinking Categories of Time and Social Change, a Perspective from Kulob, Southern Tajikistan' Central Asian Survey 34(2), 2015, pp. 190-203. M. Magnus, 'Southwest and Central Asia: Comparison, Integration or Beyond?' in The Sage Handbook of Social Anthropology, Volume I, R. Fardon et al. (eds.), Sage, London, 2012, pp. 340-365. T. Mostowlansky, 'Where Empires Meet: Orientalism and Marginality at the Former Russo-British Frontier' Etude de lettres 2-3, 2014, pp. 179-196. M. Reeves, Border Work: Spatial Lives of the State in Rural Central Asia, Cornell University Press, Ithaca, 2014. M. Sökefeld, 'From Colonialism to Postcolonial Colonialism: Changing Modes of Domination in the Northern Areas of Pakistan' The Journal of Asian Studies 64(4), 2005, pp. 939-973.

${ }^{11}$ A. Horstmann and R. L. Wadley, 'Introduction: Centering the Margin in Southeast Asia' in Centering the Margin: Agency and Narrative in Southeast Asian Borderlands, A. Horstmann and R. L. Wadley (eds.), Berghahn, New York, 20o6, pp. 1-24.

${ }^{12} \mathrm{C}$. Wheeler, 'Maritime Subversions and Socio-Political Formations in Vietnamese History: A Look from the Marginal Center (mien Trung)' in New Perspectives on 
not a contradiction, but an acknowledgment of the co-presence of historical forces that place a locale and its people both in the centre and at the margins, sometimes on different scales and at different historical junctures. In this article, I attempt to trace the ephemeral character of conviviality-the coming and going of a shared lifeacross the Wakhan and beyond the arbitrary border separating Central and South Asia and demonstrate that it is marked precisely by such processes of temporal and spatial transformation.

Such an endeavour requires a careful introduction to both the silence and the specific instances of conviviality, and the historical processes that underlie them. Thus, in the following section, I will introduce Karimabad in Pakistan and Khorog in Tajikistan as part of an overarching yet fragmented region. In the second part, I will focus on the defining modes of connectedness and disconnection between and beyond these places in the past and the present. Finally, in the third part of the article, I will explore forms of conviviality across the frontier that are ephemeral, mediated and marked by specific relations of power.

\section{Two 'marginal hubs' in post-Cold War borderlands}

Over the past few years, many of my friends from northern Pakistan have circulated increasing amounts of information about the region's potential for wider connectivity across the borders with Afghanistan and China. Both the development of the 'China-Pakistan Economic Corridor' (Pakistan Chin iqtesadi rahdari or CPEC) connecting Kashgar in Xinjiang with the port of Gwadar on the Arabian Sea and intensified interaction between Pakistan and the republics of Central Asia have played an influential role. A great deal of the information on these developments was shared via social media, including on Facebook and Twitter, and in the shape of links to articles, policy documents, pictures, and videos in English, Urdu, and local languages (Burushaski, Shina). Amidst a government-orchestrated campaign promoting 'Pakistan-China friendship' (Pakistan Chin dosti), people of diverse professional backgrounds, ranging from school teachers, nongovernmental organization (NGO) employees, and officials to local entrepreneurs, embraced the idea of 'infrastructure-to-be' not only

the Historiography of Southeast Asia: Continuing Explorations, M. A. Aung-Thwin and K. R. Hall (eds.), Routledge, London, 2011 , pp. 141-1 $5^{6 .}$ 
with hope and desire, ${ }^{13}$ but also with a sense of nostalgia for the past.

At the beginning of 2015 , some of my friends from Pakistan shared via Facebook the scanned version of an official letter from the preInternet era. In the 1992 letter, an official from a village in the Ghizer district of today's Gilgit-Baltistan administrative territory (previously the Northern Areas) addresses the then prime minister of Pakistan, Nawaz Sharif, with a proposal for the construction of a road link between the town of Gilgit and Tajikistan. The proposal includes a meticulous assessment of already existing infrastructure and the costs of building new stretches of road. The official writes in English:

$[\mathrm{W}]$ ith the breakdown of communism a new era of renaissance of the Muslim world has dawned. The Northern Areas of Pakistan is luckily located at the epicentre of the world populations. It has attained enormous strategic importance with the creation of new Muslim republics of central Asia. ... Development of land route linking Karakorum Highway with Tadzhikistan as early as possible would be of immense importance and to the advantage of both the countries for establishing trade. ... This is a traditional trade link between Ishkomen in Northern Areas and Pamirs in Afghanistan and was used by Afghan refugees very conveniently while coming to Gilgit. It is less mountainous, easy to maintain and being outside monsoon range gets very little precipitation, therefore, can be kept fit for vehicular traffic during winter like KKH [Karakoram Highway] at Khunjerab pass.

In the letter, the official from Ghizer designates his region as an 'epicentre' in a post-Cold War world in which abandoned forms of connectivity need to be re-established and revived. Asserting that his proposed route is the 'shortest and most economical', he argues for reconnection on the basis of economic profit and 'progress', which are strategically organized along the lines of a shared Muslim identity. ${ }^{14}$

${ }^{13}$ P. Harvey and H. Knox, 'The Enchantments of Infrastructure' Mobilities 7(4), 2012, pp. 521-536. M. Reeves, 'Infrastructural Hope: Anticipating "Independent Roads" and Territorial Integrity in Southern Kyrgyzstan' Ethnos, 82 (4), 201 7, pp. 711 737 .

${ }^{4}$ Marsden, Trading Worlds, p. xi, points to the salience of Afghanistan and overland travel in the work of the Indian Muslim philosopher Muhammad Iqbal. Iqbal, whose work still widely reverberates in today's Pakistan, advances the notion of Muslim selfhood as mobile, often distinguishing between sea travel as tied to colonialism and overland routes as more authentic. In this regard, Javed Majeed also argues that Iqbal, himself a pivotal figure in Pakistan's emergence as an Islamic polity, saw migration, and the journey more generally, as a founding act of the self, paralleling the hijra from Medina to Mecca. See J. Majeed, 'Muhammad Iqbal: Islam, Aesthetics and Postcolonialism' in Postcolonialism and Islam: Theory, Literature, Culture, Society and Film, G. Nash, K. Kerr-Koch, and S. E. Hackett (eds.), Routledge, London and New York, 
This two-fold justification for establishing connectivity across ethnic and sectarian lines still resonates throughout today's Gilgit-Baltistan.

The fact that the letter dates from two decades ago signifies a lack of change and emphasizes the persistence of Cold War boundaries that criss-cross the region. When the official from Ghizer signed and dated his letter to the prime minister in mid-1992, Tajikistan had already begun to descend into a period of civil war that lasted until 1997. Since then, state-to-state interaction between Pakistan and Tajikistan has been minimal. Today, efforts to physically link the two countries are often localized and remain part of a discourse on connectivity that is still to come. ${ }^{15}$ At the same time, the circulation of the letter, evoking the image of a united and well-connected Muslim world at large, points to the desire for a past with a future. ${ }^{16}$ Against this backdrop, one can characterize the two places explored in this article-Karimabad in northern Pakistan and Khorog in eastern Tajikistan-as having been shaped both by the opening of the region in the course of Chinese economic globalization and by the afterlives of Cold War discourses and practices.

\section{Karimabad}

Karimabad is located in the Hunza district of Gilgit-Baltistan in the northernmost part of Pakistan. According to Hermann Kreutzmann, it had a population of 5,168 in $1998 .{ }^{17}$ The settlement, whose old stone buildings and new concrete houses sprawl over the slopes beneath the imposing Baltit fort, received its current name in 1983 in honour of Prince Shah Karim Al Hussaini Aga Khan IV. The Aga Khan IV is the current Imam of the Nizari Ismailis ${ }^{18}$ and is revered by a majority of

2015 , p. 40, as well as J. Majeed, Muhammad Iqbal: Islam, Aesthetics and Postcolonialism, Routledge, New Delhi, 2009, pp. 90-115.

${ }^{15}$ See, for example, Mostowlansky, 'Building Bridges' on Afghanistan and Tajikistan.

${ }^{16}$ Reeves, 'Infrastructural Hope', p. 717.

${ }^{17}$ H. Kreutzmann, 'Preservation of Gilgit-Baltistan's Cultural Heritage as a Key to Development' in Preservation of Built Environment and Its Impact on Community Development in Gilgit-Baltistan, H. Kreutzmann (ed.), Centre for Development Studies, Berlin, 2013, p. 22. The last census dates to 1998 and more recent population figures are not readily available. However, there is an ongoing 2017 census whose results have not yet been published at the time of writing.

${ }^{18}$ F. Daftary, The Isma'ilis: Their History and Doctrines, Cambridge University Press, Cambridge, 2007. Steinberg, Isma'ili Modern. S. Mukherjee, Ismailism and Islam in 
the people in Karimabad. The Aga Khan IV is also the chairman of the Aga Khan Development Network (AKDN), which has been active in the greater region for several decades. ${ }^{19}$

People in Karimabad describe their town as diverse and marked by plurality and mobility. Most inhabitants of Karimabad are speakers of Burushaski, but other local languages such as Domaaki, Shina, and Wakhi are also spoken. Languages commonly used in everyday encounters with people from outside the region include Urdu and English. While almost nobody speaks, reads, or writes Persian today, the language continues to symbolize prestige because of its status as the language of literature and religion prior to the region's closer association with the Pakistan nation state. Before the dissolution of the princely state of Hunza (Kanjut) in 1974, today's Karimabad served as the seat of the ruler (mir, tham) of Hunza and thus as a centre of political power. ${ }^{20}$ Although the settlement has lost this status, people in Karimabad still see their town as oscillating between centrality and marginality, depending on the sphere of influence and point in time in question. Its location along an ancient trade route ${ }^{21}$ is historically evocative and often compared to forms of connectivity provided through the construction of more recent endeavours such as the Karakoram Highway. ${ }^{22}$ Karimabad is also a significant regional centre for tourism ${ }^{23}$ and the 'past in the present' ${ }^{24}$ is a vital part of everyday discourse, not least because many people now largely sustain the present by selling the place's past to visitors. Neither the past

Modern South Asia: Community and Identity in the Age of Religious Internationals, Cambridge University Press, Cambridge, 2017.

${ }^{19}$ T. Mostowlansky, 'Development Institutions and Religious Networks in the Pamirian Borderlands' in Routledge Handbook of Asian Borderlands, A. Horstmann, M. Saxer, and A. Rippa (eds.), Routledge, London and New York, 2018, pp. $3^{8} 5^{-}$ 395. D. M. Poor, Authority without Territory: The Aga Khan Development Network and the Ismaili Imamate, Palgrave Macmillan, New York, 2014. M. Ruthven, 'The Aga Khan Development Network and Institutions' in A Modern History of the Ismailis: Continuity and Change in a Muslim Community, F. Daftary (ed.), I.B. Tauris, London and New York, pp. 189-220.

${ }^{20}$ Daftary, The Isma'ilis, p. 495 .

${ }^{21}$ I. Stellrecht, 'Passage to Hunza: Route Nets and Political Process in a Mountain State' in Karakoram in Transition: Culture, Development, and Ecology in the Hunza Valley, H. Kreutzmann (ed), Oxford University Press, Oxford, 20o6, pp. 191-216.

${ }^{22}$ H. Kreutzmann, 'The Karakoram Highway: The Impact of Road Construction on Mountain Societies' Modern Asian Studies 25(4), 1991, pp. 711-736. Rippa, 'Across the Khunjerab Pass'.

${ }^{23}$ Kreutzmann, 'Preservation of Gilgit-Baltistan', p. 14.

${ }^{24}$ M. Bloch, 'The Past and the Present in the Present' Man 12(2), 1997, pp. 278 292. 
nor the present is thought of as simply linear or homogenous. For instance, Sherullah, a man in his fifties whom I befriended in 2013, has repeatedly told me that people in Karimabad lived in 'medieval' conditions of dirt, disease, and immobility before the construction of the Karakoram Highway in the 1970s. However, others contradicted this view and commented positively on the settlement's deeper past as the centre of the historical state of Hunza and a trading post along the Silk Road.

This 'charging' of the past with the present and vice versa ${ }^{25}$ ties in with political and developmental discourses of marginality to which Karimabad has been subject, both as a place at the periphery of the British empire and independent Pakistan ${ }^{26}$ and because of its location on a former Cold War boundary. In everyday life, the effects of these discourses materialize in a felt distance from urban centres in the lowland, a sense of geographical remoteness, ${ }^{27}$ repeated road construction and development initiatives from the 197 os onwards, ${ }^{28}$ and a more recent decrease in international visitors due to post-9/11 developments in Pakistan. ${ }^{29}$ At the same time, these discourses are juxtaposed with an image of Karimabad as a meeting place for people of diverse backgrounds, a centre of learning with numerous schools, and a settlement along the major artery connecting Pakistan and China.

\section{Khorog}

The town of Khorog is part of eastern Tajikistan's Gorno-Badakhshan Autonomous Region and lies some 300 kilometres (linear distance) north-west of Karimabad. The two places are separated by highaltitude terrain, two international borders (Pakistan-Afghanistan and Afghanistan-Tajikistan) and the Wakhan corridor in Afghanistan. Like Karimabad, Khorog is a diverse and multilingual place, with a range of Pamir languages, Tajik, Kyrgyz, and Russian being spoken

${ }^{25}$ N. D. Munn, 'The Cultural Anthropology of Time: A Critical Essay' Annual Review of Anthropology 21, 1992, p. 114.

${ }^{26}$ Sökefeld, 'From Colonialism to Postcolonial Colonialism'.

${ }^{27} \mathrm{~S}$. Hussain, Remoteness and Modernity: Transformation and Continuity in Northern Pakistan, Yale University Press, New Haven and London, 2015. Mostowlansky, 'Where Empires Meet'.

${ }^{28}$ H. Kreutzmann, Hunza: Ländliche Entwicklung im Karakoram, Dietrich Reimer Verlag, Berlin, 1989 .

${ }^{29}$ Kreutzmann, 'Preservation of Gilgit-Baltistan', p. 14. 
in everyday life. Khorog, now with a population of around 30,0oo, developed from a village into a larger settlement when Russian colonial forces arrived at the end of the nineteenth century and built a military garrison there (post Khorogskii). ${ }^{30}$

In this sense, Khorog has functioned as a hub throughout the twentieth century and up to the present day. The very foundation of the settlement is rooted in imperial encounters that pulled its inhabitants into the orbit of Russian influence. As Alexander Morrison argues, the link between Russia and the Pamirs not only reflected geostrategic interests in the region that resulted from territorial competition with the British empire located to the south; it was also founded on a purported racial affinity marked by common Aryan descent. ${ }^{31}$ During Khorog's transformation into a Soviet administrative centre and bustling town on the Pamir Highway, ${ }^{32}$ the idea of a special cultural and aesthetic connection between Russia and the Pamirs persisted and was, as I will discuss later, amplified by Soviet 'provisioning' and the introduction of Soviet modernity. Post-Cold War development ${ }^{33}$-often fostered by the Aga Khan Development Network-and border openings with Afghanistan ${ }^{34}$ and China ${ }^{35}$ have resulted in the revival of old connections and the establishment of new networks beyond Khorog. Many of my interlocutors in the town have discussed these events-linked to processes of ethnicity, religious reform, and economic change-as situated against the backdrop of the fundamentally transformative Soviet experience. Nevertheless, like Karimabad, Khorog has often been labelled, somewhat paradoxically, as both marginal and central

${ }^{30}$ F. Bliss, Social and Economic Change in the Pamirs (Gorno-Badakhshan, Tajikistan), Routledge, London and New York, 2006, p. 73. M. A. Bubnova, Istoriia GornoBadakhshanskoi avtonomnoi oblasti: S drevneishikh vremen do noveishego perioda, Vol. I, Paivand, Dushanbe, 2005, p. 369. A. Morrison, The Russian Conquest of Central Asia: A Study in Imperial Expansion, Cambridge University Press, Cambridge, forthcoming.

${ }^{31}$ Morrison, The Russian Conquest.

${ }^{32}$ T. Mostowlansky, Azan on the Moon: Entangling Modernity along Tajikistan's Pamir Highway, University of Pittsburgh Press, Pittsburgh, 201 7. N. A., 7o-sol shahri Khorugh, Dushanbe, Ma'rifat, 2002.

${ }^{33}$ Bliss, Social and Economic Change, pp. 297-343.

${ }^{34}$ Mostowlansky, 'Building Bridges'. Remtilla, 'Re-Producing Social Relations'.

${ }^{35}$ T. Kraudzun, 'From the Pamir Frontier to International Borders: Exchange Relations of the Borderland Population' in Subverting Borders: Doing Research on Smuggling and Small-Scale Trade, B. Bruns and J. Miggelbrink (eds.), VS Verlag für Sozialwissenschaften, Wiesbaden, 2011, pp. 171-191. T. Mostowlansky, 'The Road Not Taken: Enabling and Limiting Mobility in the Eastern Pamirs' Internationales Asienforum/International Quarterly for Asian Studies 45(1-2), 2014, pp. 153-170. 
in political and developmental discourses: it has featured as an outpost on the periphery of the Russian Empire, a dead-end town along the once heavily militarized Soviet-Afghan border, and a mountainous way station along the contemporary trade route connecting Urumqi and Kashgar in China with Tajikistan's capital Dushanbe, but also as a regional centre of political power, a place of strategic importance, a site of continuous infrastructural investment, and a town with two universities.

For the people of Khorog whom I have encountered since 2008, the co-presence of centrality and marginality is an intrinsic and normalized part of their daily lives. While the fact that both Khorog and Karimabad are predominantly inhabited by Ismailis might provide the most obvious link between the two places, their status as 'marginal hubs' in geographical proximity yet fundamentally different historical and political contexts constitutes an equally salient connection. In the following section, I situate the two places and their people amidst processes that have contributed to an ambivalent sense of a shared, yet divided, history. I argue that these parallel modes of connection and detachment have emerged during imperial endeavours, the construction of a Cold War frontier, and specific forms of post-Cold War globalization.

\section{Modes of connectedness and disconnection}

Looking back in history, there is a range of different 'scale-making projects' that inform the ways people in Karimabad and Khorog situate themselves in space and time. I borrow the term 'scale-making projects' from Anna Tsing, who uses it to refer to forms of 'spatial dimensionality' that provide the foundation for particular takes on the world, ranging from 'microscopic' to 'planetary'. ${ }^{36}$ Examples of people's participation in such scale-making projects include everyday practices such as school children singing the national anthems of Tajikistan and Pakistan, nostalgia for and visions of a united frontier zone, debates at a wedding in Hunza on the Balawaristan nationalist movement seeking independence for Gilgit-Baltistan, ${ }^{37}$ similar discussions in Khorog's city park on the distinction between

\footnotetext{
${ }^{36}$ Tsing, Friction, p. $5^{8 .}$

${ }^{37}$ M. Sökefeld, 'Bālāwaristān and Other Imaginations: A Nationalist Discourse in the Northern Areas of Pakistan' in Ladakh: Culture, History and Development between
} 
Pamiris and Tajiks, and road construction workers telling me that the difference between a Shughni speaker in Khorog and one on the Afghan side just across the river is 'socialism'. They also include reverence and respect for the 'royal' family in Hunza and Khorogis expressing feelings of superiority towards Bartangis from a nearby mountain valley. And they materialize in people's active involvement in events and institutions of the global Ismaili Jamat ('community'), which is evoked in prayers, development initiatives, shared religious rituals, and student exchange programmes.

Amidst this wealth of references to imperial, national, transnational, and local scale-making projects, connectivity between Karimabad and Khorog is diffuse, flickering here and there in everyday conversations and institutional settings, and currently centrally organized around the figure of the Aga Khan IV as a 'social, political, and spiritual leader' ${ }^{38}$ As I argue below, the oscillating quality of connectivity and disconnectedness between the two places cannot be naturalized solely on the basis of different imperial and national contexts; it is also rooted in their respective local histories.

\section{Imperial ties and Cold War division}

A take on pre-imperial history that is popular among people in Khorog goes as follows. Before the Russians arrived in the region, Shughnan, the area in which today's Khorog is situated, used to be a crossroads for trade and was linked to the mountain valleys of northern Pakistan. However, the inhabitants of Shughnan also suffered frequent attacks by 'Afghans' (Afghonho), ${ }^{39}$ and eventually their leaders sent a petition to the Russian tsar, who offered protection and integrated the region into the Russian empire.

This particular view of Badakhshani history, which sees Russian expansion as a benign process of 'joining together' (prisoedinenie),

Himalaya and Karakoram, M. van Beek, K. Brix Bertelsen, and P. Pedersen (eds.), Aarhus University Press, Aarhus, 1999, pp. 350-368.

${ }^{38}$ Steinberg, Isma'ili Modern, p. 10.

${ }^{39}$ The use of the term afghon in Khorog is ambiguous. It refers to citizens of Afghanistan more generally, including Pamir language-speakers just across the border river, but can also be used more specifically to denote people coming from other parts of Afghanistan to Shughnan (including Pashtuns, Tajiks, Uzbeks, and so on). In the historical narrative discussed here, the latter is the case-that is, it evokes the notion of outsiders invading the region. 
reverberates in local legends and stories. ${ }^{40}$ Soviet and post-Soviet historiography has reinforced this interpretation by emphasizing the role of the petition to the Russians, ${ }^{41}$ ultimately popularizing it as a symbol of Pamiri-Russian friendship that surfaces in schoolbooks, media discourse, and mundane conversations. Moreover, the narrative of a special and benevolent relationship between Russians and the inhabitants of Gorno-Badakhshan is an important element in understanding the changing modes of connectedness in the region under colonial and socialist conditions. The establishment of a Russian protectorate at the Tajik-Afghan border at the end of the nineteenth century directly fed into the process of introducing Soviet power and securing a loyal Cold War borderland by offering alternative economic, cultural, and aesthetic forms of connectivity. ${ }^{42}$ From the 193 os onwards, the Soviets militarized Gorno-Badakhshan's borders with Afghanistan and China in an attempt to re-route people in Khorog towards a new and distinct historical trajectory. ${ }^{43}$

In the case of Karimabad, imperial ties took a rather different shape and resulted in narratives that reflect changing forms of domination from the end of the nineteenth century and throughout the twentieth century. The re-establishment of the British Gilgit Agency in 1889 is important in this regard, ${ }^{44}$ as is the British conquest of Hunza in $1892 .{ }^{45}$ The Gilgit Agency in particular can be seen as a British reaction to Russian expansion in Central Asia and thus as part of broader geopolitical developments. ${ }^{46}$ Despite British intervention, Hunza remained a separate political entity, with the mir of Hunza

${ }^{40}$ D. Beben, 'Local Narratives of the Great Game in Badakhshan', unpublished manuscript. Morrison, The Russian Conquest.

${ }^{41}$ Beben, 'Local Narratives'. Bubnova, Istoriia Gorno-Badakhshanskoi avtonomnoi oblasti, p. 356 .

${ }^{42}$ B. Kassymbekova, Despite Cultures: Early Soviet Rule in Tajikistan, University of Pittsburgh Press, Pittsburgh, 2016. M. Saxer, 'A Spectacle of Maps: Cartographic Hope and Anxieties in the Pamirs' Cross-Currents 21, 2016, pp. 111-136.

${ }^{43}$ P. Bergne, The Birth of Tajikistan: National Identity and the Origins of the Republic, I.B. Tauris, London, 2007, p. 99. Kraudzun, 'From the Pamir Frontier to International Borders'. D. Straub, 'The Ismailis and Kirghiz of the Upper Amu Darya and Pamirs in Afghanistan: A Micro-History of Delineating International Borders', MA thesis, Indiana University, 2013.

${ }^{44}$ Sökefeld, 'From Colonialism to Postcolonial Colonialism', p. 944.

${ }^{45}$ A. H. Dani, History of Northern Areas of Pakistan, National Institute of Historical and Cultural Research, Islamabad, 1991, p. 273.

${ }^{46}$ Dani, History of Northern Areas, p. 283. R. Huttenback, 'The Great Game in the Pamirs and Hindukush: The British Conquest of Hunza and Nagar' Modern Asian Studies 9(1), 1975, pp. 1-29. 
continuing to reside in the fort at Baltit above today's Karimabad. This was the case until 1974, when Pakistan's president Zulfikar Ali Bhutto dissolved the princely state and annexed it to the Northern Areas, which were under the control of the federal government.

Before the dissolution of the princely state of Hunza, another geopolitical process held the region in its sway. The decolonization and partition of British India in 1947 put northern Pakistan at the heart of the conflict between India and Pakistan over control of Kashmir. This 'struggle for freedom' (jang azadi) against the Maharaja of Kashmir and Indian troops has resulted in very different historical narratives, ranging from nationalist depictions of a united struggle to more localized impressions that the event simply represented a transition from British to Pakistani colonial domination. ${ }^{47}$ These issues have not lost their general importance for the people of Karimabad and Gilgit-Baltistan. Even though their major point of orientation with regard to opportunities for education and work is lowland Pakistan, including Karachi, Lahore, and Islamabad, the unresolved status of the Kashmir conflict and Gilgit-Baltistan's resulting lack of full constitutional recognition have led to ambivalent attitudes towards the nation state. ${ }^{48}$

Karimabad and Khorog are both located in borderlands that have had complex, if not uneasy, relations with their superordinate political entities and centres of political power in the course of the twentieth and the early twenty-first centuries. Gorno-Badakhshan, for instance, went through a history of Russian colonial domination, processes of massive social transformation as part of the Soviet Union, and, in the post-Soviet period, the Tajik civil war, with its still palpable effects. As for Gilgit-Baltistan, it has experienced a long period of outside domination-first in the British colonial framework and then within the context of the Pakistani nation state-that is perceived as having led to a lack of self-determination and local agency. In both

${ }^{47}$ M. Sökefeld, 'Jang Azadi: Perspectives on a Major Theme in Northern Areas History' in The Past in the Present: Horizons of Remembering in the Pakistan Himalaya, I. Stellrecht (ed.), Rüdiger Köppe Verlag, Köln, 1997, pp. 61-81. Sökefeld, 'From Colonialism to Postcolonial Colonialism'.

${ }^{48}$ N. K. Ali, 'States of Struggle: Politics, Religion, and Ecology in the Making of the Northern Areas, Pakistan', PhD diss., Cornell University, 2009. N. Ali, 'Poetry, Power, Protest: Reimagining Muslim Nationhood in Northern Pakistan' Comparative Studies of South Asia, Africa and the Middle East 32(1), 201 2, pp. 13-24. C. Haines, Nation, Territory and Globalization in Pakistan: Traversing the Margins, Routledge, London, 2012. Hussain, Remoteness and Modernity. 
places, these processes of transformation have gone hand in hand with particular projects of modernization and societal development that I summarize under the rubric of 'development work'. In the following, I seek to show that this 'development work' has had paradoxical impacts on people's lives in Karimabad and Khorog: while it is intended to introduce 'progress' to the area, it has also often highlighted the region's marginality and disconnection.

\section{Development work}

Soviet efforts to reconfigure the border area adjacent to Afghanistan and China were marked by the establishment of distinction. Starting in the 193 os, the separation between 'socialist' and 'capitalist' realms was tied to ideological and economic considerations. ${ }^{49}$ Yet it also materialized as border infrastructure as well as general social and infrastructural development in Gorno-Badakhshan. This included the construction of new roads, hospitals, and schools, the promotion of gender equality, access to privileged provisioning of basic goods, educational opportunities, and mobility within the Soviet Union. ${ }^{50}$ In Khorog, and Gorno-Badakhshan more generally, people refer to this process as 'Moscow provisioning' (Moskovskoe obespechenie), which denotes Soviet attempts to create 'centres' in selected places all over the Union. ${ }^{51}$

As a centre in the periphery, Khorog and other places in GornoBadakhshan were marked by distinction from their surroundings within the Soviet Union. Moreover, Khorog's location at the Afghan border also turned the place into a symbol of progress in contradistinction to the 'undeveloped' Afghan side across the river. In 2013, Shirinbek, an elderly man with whom I discussed Soviet development in Khorog, characterized the Soviet distinction between the two different realms along the Afghan border as one 'between Soviet people who became modern (souremennye)

${ }^{49}$ C. Shaw, 'Friendship Under Lock and Key: The Soviet Central Asian Border, 1918-34' Central Asian Survey 30(3-4), 2011 , pp. 331-348.

${ }^{50}$ Bliss, Social and Economic Change. T. Kraudzun, 'External Support and Local Agency: Uncertain Transformations of Livelihoods in the Pamirian Borderland of Tajikistan' in Mapping Transition in the Pamirs: Changing Human-Environmental Landscapes, H. Kreutzmann and T. Watanabe (eds.), Springer, Dordrecht, 2016, pp. 159-179. Mostowlansky, Azan on the Moon. Remtilla, 'Re-Producing Social Relations'.

${ }^{51}$ Reeves, Border Work, p. 114. 
and uncivilized (netsivilizovannye) people in Afghanistan, India and Pakistan'. Shirinbek's statement does not mean that the countries mentioned were not sites of development for national or international actors. In fact, Afghanistan itself was an important site for Soviet development initiatives ${ }^{52}$ and, as I will discuss below, northern Pakistan was subject to its own distinctive path of development throughout the second half of the twentieth century. However, we can understand Shirinbek's sentiment, which is widely shared by members of his generation, as based on the observation that there was an obvious difference between the Tajik and the Afghan sides of the river that was indexed through dichotomies such as roads versus paths, electricity versus candles, and concrete houses versus mud-brick huts. The establishment of distinction in this 'previously borderless' (sarhad nabud) region also signified a new form of connectivity rendering Moscow closer than Kabul and southern Kyrgyzstan closer than northern Pakistan. In our conversation, Shirinbek described this connectivity as an embodied cultural closeness that led to Khorogis looking and behaving 'like Russians' (rangi rusho)—a process that he identified with Pamiris starting to wear clothes from Moscow, speak Russian fluently, and drink vodka.

Development in Karimabad, and in other parts of today's GilgitBaltistan, has a different genealogy and is closely linked to the establishment of Ismaili institutions in the region. In this regard, the account of Ismaili activist and local historian Qudratullah Haji Beg provides detailed insights into interactions between the Aga Khan III in Bombay and his supporters in the Central Asian borderlands that led to the construction of community centres and educational institutions. ${ }^{53}$ Beg describes negotiations, fundraising, construction, and political intrigues between the 193 os and the $195^{\circ}$ s, situating them within a political environment in which local people-even across colonial and then Cold War boundaries-were considered part of a 'Central Asian Ismaili community' (Sentral eshyaki jama'at). Border closures and the decreasing connectivity between the different borderlands further directed people's orientation in Karimabad and other places on the British side of the frontier towards Bombay and,

\footnotetext{
${ }^{52}$ P. Robinson and J. Dixon, Aiding Afghanistan: A History of Soviet Assistance to a Developing Country, Columbia University Press, New York, 2013. T. Nunan, Humanitarian Invasion: Global Development in Cold War Afghanistan, Cambridge University Press, Cambridge, 2016.

${ }^{53}$ Q. H. Beg, Tarikh-e tamir-e Sentral Jama'atkhana-ye Gilgit (The Construction of the Central Jama'atkhana of Gilgit), no publisher, Baltit, 1967.
} 
after partition, towards Karachi. In this respect, the infrastructures of the British empire and independent Pakistan played a decisive role, as did linguistic preferences, which began to turn to English and Urdu and away from Persian, which had previously served as the lingua franca in the region. For instance, in 1940, Sultan Muhammad Shah Aga Khan III addressed his 'spiritual children' in 'the Northern Frontiers of India, such as Chitral, Hunza, Gilgit and Badakhshan' via Delhi Radio and called on them to educate the youth and 'to learn European languages and the English language'.54 Since there were only a few hundred literate people in the whole of Hunza, broader access to education first had to be provided. Soon, Aga Khan institutions had constructed 18 schools in Hunza, followed by another 6o comparable schools by $1973 .{ }^{55}$ The establishment of schools and, therefore, access to education have been part of broader processes of development in Hunza in general and in Karimabad in particular. From the 1970 onwards, large-scale road construction made travel to and from Hunza much faster and easier. The construction of the Karakoram Highway connecting Pakistan and China is of particular importance in this respect. In 1982, the road was declared open for regular traffic between Pakistan and China, ${ }^{56}$ thus providing the inhabitants of Karimabad with road access to both the Pakistani lowlands and Kashgar in nearby Xinjiang. Largerscale development projects followed the newly established transport network $^{57}$ and, in 1982, the Aga Khan Foundation, part of the Aga Khan Development Network (AKDN), established the Aga Khan Rural Support Programme. ${ }^{58}$ Today, in the broader framework of northern Pakistan, the AKDN constitutes only one of many different institutions active in the development sector. However, in Karimabad and Hunza more generally, AKDN agencies are the principal actors in

\footnotetext{
${ }^{54}$ F. M. Hunzai, 'A Living Branch of Islam: Ismailis of the Mountains of Hunza' Oriente Moderno 84, 2004, p. 157.

${ }^{55}$ Kreutzmann, Hunza, pp. 162-163. On the history of education in Hunza, see also A. Benz, 'Education and Development in the Karakorum: Educational Expansion and Its Impact in Gilgit-Baltistan, Pakistan' Erdkunde 67(2), 2013, pp. 123-136.

${ }^{56}$ Kreutzmann, Hunza, p. 35 .

${ }^{57}$ H. Kreutzmann, 'The Karakoram Highway as a Prime Exchange Corridor Between Pakistan and China' in Proceedings of the Regional Workshop Integrated Tourism Concepts to Contribute to Sustainable Development in Mountain Regions Gilgit/PakistanKashgar/P.R.China, Oct 8-I4, 20o8, H. Kreutzmann, G. A. Beg, L. Zhaohui, and J. Richter (eds.), InWEnt, Bonn, 2009, p. 25.

${ }^{58}$ G. Wood, A. Malik, and S. Sagheer (eds.), Valleys in Transition: Twenty Years of AKRSP's Experience in Northern Pakistan, Oxford University Press, Oxford, 2006.
} 
social and infrastructural development. It is this trajectory of outside influence that people in Karimabad are referring to when they speak of a transition from 'medieval' to 'modern' times, drawing a distinction between educated Hunza and other 'illiterate' regions of Pakistan. ${ }^{59}$

The distinction between centres of learning at the margins, exemplified by Karimabad and Khorog, and lesser-educated lowlands reverses Ernest Gellner's take on Muslim societies in which learning is associated with urban centres where political power and trade are concentrated. ${ }^{60}$ Working against such a binary, the effects of 'development' in the two places in the course of the twentieth century suggest that we can observe both constructions and deconstructions of marginality, rendering Karimabad and Khorog simultaneously marginal and central. ${ }^{61}$ This is illustrated by colonial, socialist, and post-colonial boundary-making projects and subsequent approaches to modernization. In the post-Cold War period, these efforts have been merged in an envisioned micro-regional integration of places in Afghanistan, Pakistan, and Tajikistan. This process has been centred on the figure of the Aga Khan IV, who communicates and puts into practice-via public speeches, 'edicts' (farman), and development projects-his vision for the reintegration of Ismaili populations once separated by ideological frontiers.

\section{Post-Cold War humanitarianism}

In Tajikistan, the end of the Cold War in 1991 marked the beginning of the Tajik civil war, which ravaged the country from 1992 to $1997 .{ }^{62}$ This event influenced recent processes of transformation in GornoBadakhshan because it attracted an influx of outside actors to the region to help deal with the humanitarian crises that accompanied the civil war. In the winter of 1992-93, approximately 180 ,ooo inhabitants of Gorno-Badakhshan and several tens of thousands of

${ }^{59}$ T. Mostowlansky, 'Humanitarianism across Mountain Valleys: "Shia Aid" and Development Encounters in Northern Pakistan and Eastern Tajikistan' in Mapping Transition in the Pamirs: Changing Human-Environmental Landscapes, H. Kreutzmann and T. Watanabe (eds.), Springer, Dordrecht, 2016, pp. 229-244.

${ }^{60}$ E. Gellner, Saints of the Atlas, Weidenfeld and Nicolson, London, 1969.

${ }^{61}$ See also S. F. Green, Notes from the Balkans: Locating Marginality and Ambiguity on the Greek-Albanian Border, Princeton University Press, Princeton, 2005.

${ }^{62}$ K. Nourzhanov and C. Bleuer, Tajikistan: A Social and Political History, ANU E Press, Canberra, 2013, pp. 323-335. 
refugees, many of them in Khorog, were cut off from other parts of Tajikistan. ${ }^{63}$ In addition, refugees from Tajikistan went to Afghanistan and other Central Asian republics, ${ }^{64}$ as well as to Chitral in Pakistan (although there are no reports of Tajiks in Hunza). ${ }^{65}$

Facing starvation after the Soviet system of provisioning had collapsed in Gorno-Badakhshan, people in Khorog and other places became dependent on alternate lines of support from the outside. ${ }^{66}$ The first and most important actor that entered the region at that stage was the Aga Khan Foundation (AKF), which related to the Pamirs not only on the basis of the above-mentioned religioushistorical ties, but also against the backdrop of several decades of development work in the immediate vicinity. As oral and written reports of the AKF's early take on Khorog and Gorno-Badakhshan in 1993 show, the foundation's long-standing experience in northern Pakistan initially informed perceptions of the broader region (including Gorno-Badakhshan and Gilgit-Baltistan) as 'culturally' and 'topographically' uniform. However, it soon became clear that 70 years of Soviet modernization had significantly shaped not only the region's infrastructure, but also its social organization and people's expectations regarding living standards and mobility. ${ }^{67}$

The recognition of difference between the region's various communities in the aftermath of the Cold War has, on the one hand, led to the adaptation of development templates and approaches. On the other hand, it has also contributed to the launching of projects that aim to transcend difference by establishing contact, for instance by building bridges and cross-border markets as well as by fostering professional development, trade, and educational mobility. ${ }^{68}$ The Aga

${ }^{63}$ Bliss, Social and Economic Change, p. 4.

${ }^{64}$ Human Rights Watch, 'Tajik Refugees in Northern Afghanistan: Obstacles to Repatriation', Hrw.org, online: https://www.hrw.org/reports/1996/Tajik.htm (accessed 12 May 2017).

${ }^{65}$ M. Marsden, Living Islam: Muslim Religious Experience in Pakistan's North-West Frontier, Cambridge University Press, Cambridge, 2005, p. 4o. Marsden and Hopkins, Fragments of the Afghan Frontier, p. 153, note that Pamiris coming to Chitral were not simply displaced persons, but were already connected to the place's culture and history by virtue of their family histories and Ismaili identities.

${ }^{66}$ S. Keshavjee, 'Medicines and Transitions: The Political Economy of Health and Social Change in Post-Soviet Badakhshan, Tajikistan', PhD diss., Harvard University, 1998. S. Keshavjee, Blind Spot: How Neoliberalism Infiltrated Global Health, University of California Press, Berkeley, 2014.

${ }^{67}$ Bliss, Social and Economic Change, p. 4.

${ }^{68}$ B. Bolander, 'English, Motility and Ismaili Transnationalism' International Journal of the Sociology of Language 247, 2017. C. Maertens, 'No Debt, No Business: 
Khan IV and the institutions he chairs are critical actors in this endeavour to create a common future, not only with respect to visions of development, but also in terms of the standardization of religious practice, teachings, and leadership. ${ }^{69}$ However, as Magnus Marsden and Benjamin Hopkins argue, these attempts at homogenization have not necessarily supplanted or even weakened local Ismaili identities in the region. ${ }^{70}$ Indeed, 'borderland dwellers' often contrast their local practices to those of Ismailis in other parts of the world, and particularly to those of the diasporic Khoja Ismailis, ${ }^{71}$ who hold powerful positions in the Aga Khan institutions and are physically present as administrators and volunteers. ${ }^{72}$ Thus, Ismaili development efforts and the vision of a global Ismaili community have had complex and ambivalent effects on Karimabad and Khorog. While fostering an Ismaili identity envisaged as detached from locality, they have in fact provided the ground for establishing contact across the frontier that ties in with the remembrance of a common local past.

\section{Conviviality across the divide}

As I have attempted to show in the previous two sections, links between Karimabad and Khorog are not straightforward: they are ephemeral and often marked by silence. They also lack a direct form of connectivity such as exists between, for instance, Gorno-Badakhshan and Chitral, which is marked by physical movement between the two places and facilitated by a common and active belonging to the

The Personalisation of Market Exchange in Gorno-Badakhshan, Tajikistan' in Approaching Ritual Economy: Socio-Cosmic Fields in Globalized Contexts, R. Hardenberg (ed.), RessourcenKulturen, Tübingen, 2017, pp. 159-192. Mostowlansky, 'Building Bridges'.

${ }^{69}$ On the processes of universalization that are involved in this regard, see S. Mukherjee, 'Universalising Aspirations: Community and Social Service in the Isma'ili Imagination in Twentieth-Century South Asia and East Africa' in The Shi'a in Modern South Asia: Religion, History and Politics, J. Jones and A. U. Qasmi (eds.), Cambridge University Press, Delhi, 2015 , pp. $105^{-130 .}$

${ }^{70}$ Marsden and Hopkins, Fragments of the Afghan Frontier, p. ${ }^{1} 5^{1}$

${ }^{71}$ I. S. Akhtar, 'Religious Citizenship: The Case of the Globalised Khojas' African Sociological Review 18(01), 2014, pp. 27-48. A. Nanji, 'Khojas' in Encyclopedia of Islam and the Muslim World, Volume I, R. C. Martin (ed.), Macmillan, New York, 2004, p. 393 .

${ }^{72}$ For a critique of unequal power relations in this constellation, see F. Devji, 'Preface' in The Ismailis in the Colonial Era: Modernity, Empire and Islam, M. van Grondelle, Hurst \& Company, London, 2009, pp. ix-xvi. 
Persianate sphere, ${ }^{73}$ or among the Wakhi of Afghanistan, China, Pakistan, and Tajikistan, who interact on the basis of shared language and ethnicity. ${ }^{74}$ Nevertheless, people in Karimabad and Khorog talk about each other, project a common past into the future, and occasionally meet, virtually and physically, in settings that are ordered along regimes of class, privilege, and merit. The concept of conviviality poses a challenge to theorizing this kind of connectivity if it remains, as noted above, conceptually tied to face-to-face encounters in urban spaces. For this reason, I want to decouple the concept from its usual context of urban proximity and density in order to expand its applicability. In the place of shared everyday lives, what links the people of Karimabad and Khorog is nostalgia for a past that engages with the present and the future. ${ }^{75}$ And, rather than co-residence, coexistence, and shared physical space, there is a distance that highlights the institutional, political, and social rules and norms that underlie an ephemeral and occasionally activatable conviviality. ${ }^{76}$ In the following, I discuss such instances of conviviality between Karimabad and Khorog along three main lines of enquiry: first, I look at common geography as a source of intimacy; second, I show how people in Karimabad and Khorog refer to shared ethics as a binding factor; and, finally, I turn to mobility beyond the two places and the role of media technology in negotiating translocal forms of identity.

\section{Common geography, dissected modernity}

On a summer evening in 201 1, I sat with Mamadnazar and Khilvatsho, two Pamiri men in their thirties or forties, in a garden in Khorog. We watched videos featuring speeches of the Aga Khan and, when an image of the Hunza Valley with the Baltit fort above Karimabad briefly appeared on the TV screen, Mamadnazar said: 'I knew there were brothers and sisters over there, but we have rarely seen them. I think we should go there, but it's hard when there's no connection.' Then Khilvatsho added: 'They helped us in $1992 \ldots$ in 1993.' And

\footnotetext{
${ }^{73}$ Marsden and Hopkins, Fragments of the Afghan Frontier, p. 152.

${ }^{74}$ Kreutzmann, Pamirian Crossroads.

${ }^{75}$ M. Pickering and E. Keightley, 'The Modalities of Nostalgia' Current Sociology 54(6), 2006, pp. 919-941.

${ }_{76}$ Freitag, 'Cosmopolitanism and Conviviality', p. 376.
} 
Mamadnazar continued: 'And they still help us today so that we live better-not rich, but average.'

Mamadnazar and Khilvatsho are cousins and grew up in Khorog. Now they spend most of their lives apart and travel between Khorog, Murghab in the eastern Pamirs, the Tajik capital Dushanbe, Kumsangir in south-western Tajikistan, and Moscow for work and family visits. Both thus orient towards a geographical framework that the Tajik nation state and Moscow as a centre of economic potential have laid out. Against this backdrop, the discussion that emerged on that evening in 2011 highlighted the faraway-nearby ambivalence that people in Karimabad and Khorog often referred to when talking about each other.

Their discussion departed from the brief images of northern Pakistan on TV and quickly turned to the importance of historical developments. Khilvatsho recalled: 'Before the Soviet Union, the road was open, and then they used the river as a border, set up barbed wire, and relatives stayed on different sides of the border.' Mamadnazar added, referring to pan-Soviet education: 'After that, we all had a very strict upbringing [vospitanie] in the trade union [profsoiuz]; with unity and brotherhood, almost like in the Qur'an, being brothers despite difference in ethnicity [national'nost'] and religion [religiia].'

Mamadnazar's take on what we might call 'Soviet conviviality' points to the analytical limitations of conviviality when viewed from postmulticultural settings in 'the West', which are often seen as in need of a revised liberalism. ${ }^{77}$ In her study of youth and state-making in Bosnia-Herzegovina, Azra Hromadžić, drawing on Michael Herzfeld's notion of nostalgia as 'edenic order', ${ }^{78}$ argues that conventional ideas associated with multiculturalism such as tolerance and openmindedness might have little relevance beyond these particular settings. ${ }^{79}$ Indeed, Mamadnazar's nostalgia for brotherhood and unity referred to a 'Soviet conviviality' marked by political intervention and boundary-making. If we apply this observation to Khorog, we see that, while cutting the place off from neighbouring areas in Afghanistan-a process people referred to as establishing 'difference' or 'distinction' (Tajik farq, Russian raznitsia) — the Soviet Union also brought with it

${ }^{77}$ Gilroy, After Empire.

${ }^{78}$ M. Herzfeld, Cultural Intimacy: Social Poetics in the Nation-State, Routledge, New York, 2005 .

${ }^{79}$ A. Hromadžić, Citizens of an Empty Nation: Youth and State-Making in Postwar Bosnia Herzegovina, University of Pennsylvania Press, Philadelphia, 2015, p. $14^{2}$. 
new forms of living together that were state-enforced, regimented, and connected to a strict, rather illiberal upbringing, but which are now often fondly remembered.

People in northern Pakistan likewise recognize this distinction as a cultural and material fact. For instance, Niaz, a man in his fifties from Karimabad, travelled several times overland from northern Pakistan to Khorog while working in gem-sector development for a NGO with offices in Pakistan, Afghanistan, Tajikistan, and the United States. When we met in autumn 2013, he told me that such overland trips were not possible anymore because of the worsening security situation in Afghan Badakhshan, but he recalled vivid memories of his previous trips. He explained how he had travelled from Gilgit to Chitral, where he crossed the Pakistan-Afghanistan border, and then continued onwards to Ishkoshim and Khorog in Tajikistan. 'On these journeys,' Niaz said, 'I saw that we're different even though we have the same traditions.' Then he continued: 'Even though you're so close, you travel across a continent. You start here in Pakistan, you cross Afghanistan where they put their women on donkeys to travel, and then you step over the next border and see mini-skirts and European houses in Khorog.'

In his description, Niaz attributed an alternate form of modernity to Khorog that he, with a mixed sense of fascination and disapproval, reproached for having become Europeanized and distant. This take on regional geography is not uncommon in Karimabad, where people imagine Badakhshan in both neighbouring Afghanistan and Tajikistan as close because of their shared history and cultural similarities,${ }^{80}$ yet distinct due to different forms of economic and political development. In this respect, it is important to note that, while my interlocutors in Khorog often defined people in Afghanistan and Pakistan as less modern, at least from their own reference point in Soviet history, my interlocutors in Karimabad perceived themselves as having received development in the course of the construction of the Karakoram Highway and the Aga Khan-funded development projects. The fact that Gorno-Badakhshan went through Soviet modernization from the 193 os onwards, yet was in need of existential support from 'brothers and sisters' in Pakistan in the 1990 (as expressed by Mamadnazar and Khilvatsho), highlights the pronounced non-linearity of modernity as

${ }^{80}$ Ali, 'States of Struggle', p. 79. 
a 'time orientation'. ${ }^{81}$ Concurrently, different degrees of development also dissected the common geography that people in both places invoked when they referred to shared mountain ranges, similar traditions, and historical interactions.

\section{Shared ethics}

On the one hand, the narratives of commonality across modern frontiers that people express in Karimabad and Khorog refer to geography and comparable lifestyles, ultimately deriving from their cohabitation within the same environment. On the other hand, they also highlight the role of shared ethics that many of my interlocutors attributed to the region's broader history. In the remembrance of how these shared ethics emerged, the figure of Nasir-i Khusraw plays a pivotal role. In many places across Gorno-Badakhshan, Afghan Badakhshan, northern Pakistan, and adjacent parts of China, Nasiri Khusraw is considered the missionary $\left(d a^{\prime} i\right)$ and philosopher who brought Ismailism to the region in the eleventh century. Born in Balkh in present-day Afghanistan, Khusraw travelled extensively throughout Central Asia and the Middle East, ultimately reaching the Fatimid court in Cairo, where he engaged with Ismailism. Upon his return to Balkh as an Ismaili missionary, he was forced to flee and seek refuge in Yumgan in today's Afghan Badakhshan. ${ }^{82}$

The adoption of Khusraw's work has taken various shapes over time and space, and has fed into identity politics in interesting ways. For instance, as a prominent figure in the project of Tajik nation building, Nasir-i Khusraw provides Ismailis in Gorno-Badakhshan with a 'critical meeting point' with 'espousers of Tajik national identity'. ${ }^{83}$ He has, moreover, become part of the global Ismaili discourse. ${ }^{84}$ While historical research shows that the trajectories of conversion and the relevance of Nasir-i Khusraw's influence in the greater region are

${ }^{81}$ G. Therborn, 'Entangled Modernities' European Journal of Social Theory 6(3), 2003, pp. 293-305.

${ }^{82}$ A. C. Hunsberger, Nasir Khusraw: The Ruby of Badakhshan, A Portrait of the Persian Poet, Traveller and Philosopher, I.B. Tauris, New York, 2003.

${ }^{83}$ D. Beben, 'The Legendary Biographies of Nasir-i Khusraw: Memory and Texualization in Early Modern Persian Isma'ilism', PhD diss., Indiana University, 2015 , p. 434.

${ }^{84}$ Steinberg, Isma 'ili Modern, p. 91. 
uneven, non-linear, and highly diversified at the local level, ${ }^{85}$ his personage nevertheless constitutes an overarching umbrella under which various ideas and practices attain a shared status.

When I first interacted with people in Hunza in 2012, they frequently asked me about my personal background, my knowledge of languages, and the places I had visited in the region. Whenever I mentioned Persian and that I had been to Tajikistan, they responded that Persian had a very high standing in Hunza, first because Persian used to be the language of the educated (prior to firmer integration into the Pakistan nation state) and second because it was the tongue in which Nasir-i Khusraw (Pir Shah Nasir) and the pirs, the religious specialists who followed him, ${ }^{86}$ spread their teachings in the region. There is of course no doubt that my personal research history in Tajikistan triggered these reactions. Yet it is also likely that people's reactions indexed their sense of a shared past between the two places as part of a common Persianate realm and the possibility of a readily activatable connectivity, thus re-emphasizing the oscillating rubrics of intimacy and difference between Karimabad and Khorog.

Nizam, a middle-aged farmer from Karimabad whom I frequently met in 2013, referred to Ismailis in northern Pakistan as having received their teachings from Nasir-i Khusraw and his pirs, thereby contrasting them with 'Khojas'-that is, the diasporic Gujarati Ismailis in Africa, Asia, and the West. On the one hand, for him, this implied reverence to ancient traditions such as chiragh-rawshan, a funeral rite that is widely known (if not practised) and attributed to Nasir-i Khusraw by Ismailis in the broader region. ${ }^{87}$ On the other hand, Nizam also saw Nasir-i Khusraw's teachings as the source of particular ethics that are based on 'rational thinking', as he put it. In this regard, Nizam foregrounded two views. The first concerned the way he thought an Ismaili should behave in order to embody principles of 'rational' and 'secular' thinking: 'Instead of fasting and performing the hajj, we should rather watch our eyes, our tongue, our hands, our feet and

${ }^{85}$ Beben, 'Legendary Biographies'.

${ }^{86}$ See also A. Iloliev, 'Pirship in Badakhshan: The Role and Significance of the Institute of the Religious Masters (Pirs) in Nineteenth and Twentieth Century Wakhan and Shughnan' Journal of Shi'a Islamic Studies 6(2), Spring 2013, pp. 155175 .

${ }^{87}$ Beben, 'Legendary Biographies', pp. 329-332. H. Elnazarov, 'The Luminous Lamp: The Practice of Chiragh-i rawshan among the Ismailis of Central Asia' in The Study of Shi'i Islam: History, Theology and Law, F. Daftary and G. Miskinzoda (eds.), I.B. Tauris, London and New York, 2014, pp. 529-541. 
our private parts.' Thus, in Nizam's view, a rationally thinking Ismaili, rather than focusing on extraordinary events, should carefully consider where to look (and what to look at), what to say, what (and whom) to touch, where to go, and how to behave sexually in everyday life.

The second aspect concerned his attitude to change, which Nizam defined as one of the most central aspects of 'rational thinking'. He emphasized that being an Ismaili in the broader region meant, in contradistinction to Sunnis and Twelver Shias, that all teachings were time-bound and that Ismailism was ultimately a 'worship of time'. Nizam's statements are linked to ethical norms and teachings that can be found among many Ismaili communities around the world. However, the interesting point for the exploration of forms of conviviality across the divide between Tajikistan and Pakistan is that he specifically tied them to Nasir-i Khusraw as a historical figure and religious authority of importance in the greater region.

In Khorog, my interlocutors' statements exhibit a number of similarities to those I would encounter later on in Karimabad. When Mamadnazar and Khilvatsho told me about their views on their 'brothers and sisters' across the border in Pakistan on that summer evening in 2011 in Khorog, they also referred to the legacy of Nasir-i Khusraw that made local Ismailis in the region distinct from other Muslims. Like Nizam, Khilvatsho highlighted rationality and ethical behaviour as central features of this distinction. He said 'We are "Godknowing" [khudoshinos], but,' he added disapprovingly, 'the Sunnis are "God-worshipping" [khudoparast].' Similarly, he emphasized the quality of insof, which 'means not to do anything bad to other people, not to tell bad things to others, [and] not to offend anyone'-an attitude that echoes Nizam's views on appropriate conduct.

Over the past couple of years, I have encountered a focus on the ideals of rationality and equity in interactions with Ismailis from different parts of the world, including Central Asia, East Africa, Europe, North America, and South Asia. In the course of these interactions, people often attributed these ideals to the humanitarian speeches and 'edicts' (farman) of the current Aga Khan. Yet my interlocutors in Khorog and Karimabad simultaneously tied them to the figure of Nasir-i Khusraw, who is not only part of global Ismaili discourse and an unifying figure in Tajik nation building, but also a representative of local distinction across the region's modern frontiers. The fact that this allowed people to navigate different scales of Ismaili identity and emphasize locality while still participating in regional, national, and transnational discourses is important for understanding 
the processes and dynamics between Karimabad and Khorog. I observed such multidirectional dynamic encounters in other fields, too. In the following, I attempt to explore two of these further fields, namely virtual and physical mobility beyond Karimabad and Khorog.

\section{Meeting places beyond the 'marginal hubs'}

In his work on the Wakhi-split between Afghanistan, China, Pakistan, and Tajikistan-Hermann Kreutzmann shows that literacy and the establishment of media platforms (such as cultural societies, literature, newspapers, and websites) play a decisive role in promoting a shared ethno-linguistic identity and various forms of conviviality across present-day political boundaries. ${ }^{88}$ With regard to Karimabad and Khorog, such shared platforms do not exist precisely because their inhabitants speak different languages (Burushaski, Urdu, and English in Karimabad and Pamir languages, Tajik, and Russian in Khorog) and are only indirectly connected via the proxies of wider religious and development networks. While conducting fieldwork in Tajikistan and Pakistan in summer 2015, I was able to observe how social media provided an additional dimension to this faraway-nearby ambivalence that I suggest defines the ephemeral character of conviviality in these places.

In July and August 2015, massive floods occurred in GornoBadakhshan and various parts of Pakistan, including GilgitBaltistan. ${ }^{89}$ Media coverage widely attributed these floods to a combination of heavy rainfall and melting glaciers due to exceptionally high temperatures. The deluge caused landslides, blocked roads, flooded homes, and drowned people. In the wake of the disaster, friends from both Gorno-Badakhshan and Gilgit-Baltistan shared news via various types of social media. They therefore engaged in a form of social-media use that, as Brett Peary, Rajib Shaw, and Yukiko

${ }^{88} \mathrm{H}$. Kreutzmann, 'Sprachenvielfalt und regionale Differenzierung von Glaubensgemeinschaften im Hindukusch-Karakorum' Erdkunde 49(2), 1995, pp. 1o61 21 . H. Kreutzmann, Ethnizität im Entwicklungsprozess: Die Wakhi in Hochasien, Dietrich Reimer Verlag, Berlin, 1996. Kreutzmann, Pamirian Crossroads.

${ }^{89}$ R. Davies, 'Tajikistan Floods: 10000 Forced to Evacuate in GornoBadakhshan Region', Floodlist.com, online: http://floodlist.com/asia/tajikistan-floods100oo-forced-gorno-badakhsan-region (accessed 9 May 2017), 2015. R. Davies, 'Pakistan Flood: Death Toll Rises to 69', Floodlist.com, online: http://floodlist.com/ asia/pakistan-floods-death-toll-rises-to-69 (accessed 9 May 2017), 2015. 
Takeuchi note, has become increasingly common around the world in the aftermath of disasters. ${ }^{90}$ This form of social-media use also highlights digital inequality, ${ }^{91}$ manifest in the uneven distribution of technological and linguistic resources. A great deal of the news about the disaster and subsequent discussions in online groups and forums focused on local developments in Khorog and along the Karakoram Highway in Hunza, allowing people to perceive the disaster as a real and shared local experience that transcended national boundaries. ${ }^{92}$ For instance, Aslisho, a young man from Khorog, introduced his reposting of an English news article on the floods in northern Pakistan with the succinct and self-explanatory comment: 'The same situation.' Other participants from Gorno-Badakhshan reacted to his statement and, in the course of the interaction in Russian and Shughni, Aslisho referred to the region as 'a place that is historically precious for our Jamoat [Ismaili community]'. Friends from Hunza, meanwhile, circulated videos of floods carrying off houses, trees, and roads in Afghan Badakhshan, Pakistan, and Tajikistan, thus promulgating a sense of geographical interdependency that was marked by shared disaster and suffering. At the same time, people throughout GornoBadakhshan and Gilgit-Baltistan linked these events to the global rise in temperature, thereby attributing broader regional and global dimensions to their misfortune. Moreover, in October and December 2015, the occurrence of earthquakes in the region ${ }^{93}$ and real-time coverage of their effects on social media-including 'mark safe' tools and charity initiatives for victims-further highlighted a type of connectivity that does not halt at the region's political boundaries; it is, rather, part of a much larger scale, connected to continental drifts and planetary developments.

${ }^{90}$ B. D. Peary, R. Shaw, and Y. Takeuchi, 'Utilization of Social Media in the East Japan Earthquake and Tsunami and Its Effectivness' Journal of Natural Disaster Science 34(1), 2012 , p. 6.

${ }_{91}$ E. Hargittai and Y. P. Hsieh, 'Digital Inequality' in Oxford Handbook of Internet Studies, W. H. Dutton (ed.), Oxford University Press, Oxford, 2013, pp. 129-15o. M. Madianou, 'Digital Inequality and Second Order Disasters: Social Media in the Typhoon Haiyan Recovery' Social Media E' Society 1(2), 2015, pp. 1-1 1.

${ }_{92}$ S. Green, P. Harvey, and H. Knox, 'Scales of Place and Networks: An Ethnography of the Imperative to Connect Through Information and Communications Technologies' Current Anthropology 46(5), 2015 , pp. 805-826.

${ }_{93}$ A. Vervaeck, 'Massive Earthquake: Murghob, Tajikistan on December 7, 2015', Earthquake-report.com, online: http://earthquake-report.com/2015/12/o7/ massive-earthquake-murghob-tajikistan-on-december-7-2015/ (accessed 9 May 2017), 2015. 
In her work on online belonging, Adi Kuntsman is critical of those who view cyberspace as 'an unproblematic site of unlimited possibilities' that predominantly entails 'passing and border crossing', 'freedom of speech', and 'community formations'. 94 Instead, she interprets interactions in cyberspace as shaped by different forms of violence and processes of exclusion that remain stored as 'archives of feelings' ${ }^{95}$ Kuntsman's critique is relevant for an understanding of what social media might mean for conviviality between Karimabad and Khorog. Digitally shared experiences beyond the two places bring them into contact with one another, and communication on such shared experiences has become part of a growing digital archive that bears witness to instances of conviviality that can be referenced, revived, looked at, distributed, and remembered. Yet the very access to such interactions and the resulting archives are subject to social and infrastructural forms of exclusion. In this regard, Sarah Green, Penny Harvey, and Hannah Knox note that it is misleading to posit a strict division between offline and online spaces, especially as neither spatial dimension is self-evident. ${ }^{96}$ In Karimabad and Khorog, the close interdependency of the two realms is omnipresent. Access to resources that enable people in both places to even use social media is dependent on offline conditions that are organized along the politics of infrastructure, status, class, and privilege. While $3 \mathrm{G}$ mobile networks and improving Internet connections are being advertised across the region, in everyday life, people's access to social media is considerably slowed down by outdated EDGE technology. ${ }^{97}$ In addition, various social-media platforms are regularly blocked, mostly for political reasons. Finally, insufficient and sporadic electricity supplies, with as little as three hours of power a day in Karimabad and regular blackouts in Khorog, make electricity a scarce resource accessible only to those who have solar panels and generators or who occupy certain social

${ }^{94}$ A. Kuntsman, Figurations of Violence and Belonging: Queerness, Migranthood and Nationalism in Cyberspace and Beyond, Peter Lang, Oxford and Bern, 2009, p. 215.

${ }^{95}$ A. Kuntsman, 'Introduction: Affective Fabrics of Digital Cultures' in Digital Cultures and the Politics of Emotion: Feelings, Affect and Technological Change, A. Karatzogianni and A. Kuntsman (eds.), Palgrave Macmillan, Basingstoke and New York, 2012 , p. 6.

${ }^{96}$ Green, Harvey, and Knox, 'Scales of Place', p. 8 o6.

${ }^{97}$ The acronym EDGE stands for 'Enhanced Data rates for GSM Evolution'. It is a pre-3G mobile technology that operates at a maximum speed of 217 kilobits per second and thus does not allow people to browse many of the websites that are online today. 
positions, such as politicians, residents of wealthy neighbourhoods, and members of reputable families.

Another factor that hinders widespread interaction via media technology across the Afghan Wakhan is the aforementioned linguistic divide that separates the people of Karimabad from those in Khorog. Institutions that have developed out of Ismaili educational and development efforts-such as the Institute of Ismaili Studies in London and the University of Central Asia-address this split by offering scholarships to study abroad, placing an emphasis on achieving fluency in English. The trajectories of mobility that these educational opportunities have created are not incidental; they are meant to guide selected people from Karimabad and Khorog towards a version of globalization that is defined by English as the global lingua franca and connectivity to urban centres in 'the West', all envisaged as uniting Ismailis from all over the world. ${ }^{98}$

In the framework of these educational programmes, including masters' programmes and teacher training, London has emerged as an especially salient meeting place. Shared flats and university dormitories serve as sites of conviviality for people from Karimabad and Khorog, integrating them into a larger community of Ismailis from Asia, East Africa, and North America. In the course of this process, while commonalities are established via shared academic and religious identities, the ambiguity of originating from nearby yet disconnected places persists. This plays out not only on the level of ethnic and linguistic identities, but also reaches into other domains, such as the sensory dimension of food. ${ }^{99}$ When my wife and I visited one of the student dormitories in London in spring 2015 for a dinner with friends from Pakistan and Tajikistan, food was literally a hot topic of discussion. The language of conversation was English, supplemented with sprinkles of Persian that some of the Pakistani students had learned as part of their study programmes. Differences were mediated by a common, transnational Ismaili identity, expressed in references to theology, as well as by the shared experience of studenthood in London.

${ }^{98}$ B. Bolander, 'English and the Transnational Ismaili Community: Identity, the Aga Khan and Infrastructure' Language in Society 45, 2016, pp. 583-6o4. Bolander, 'English, Motility and Ismaili Transnationalism'.

${ }^{99}$ J. Holtzman, Uncertain Tastes: Memory, Ambivalence, and the Politics of Eating in Samburu, Northern Kenya, University of California Press, Berkeley, 2009. D. E. Sutton, Remembrance of Repasts: An Anthropology of Food and Memory, Berg, Oxford and New York, 2001 . 
Spicy South Asian curries dominated the evening. Everybody present agreed that this kind of food does not actually belong to the high mountains of Pakistan and Tajikistan, where people traditionally prepare spiceless dishes across all divides. Our friends from Karimabad and Khorog mentioned that spices were not native to the region, which they imagined as shared, but had come from the lowlands of Pakistan. Yet they also revealed their differing historical and national belonging by expressing either love or distaste for spicy food. While our friend from Karimabad, who was used to and fond of spicy Pakistani dishes, thoroughly enjoyed his meal, our Khorogi friend emphasized, to the amusement of the whole group, his pronounced distaste for the spicy food by making faces. Khorogis generally do not link spicy food to the historical memories that would make such dishes, as David Sutton put it, 'whole' and thus their own. ${ }^{100}$ In contrast, spicy food strongly indexes Pakistani, and sometimes South Asian, belonging, despite regional variations and notions of cultural domination. Food does not just symbolize different local, national, and transnational identities (Khorog versus Karimabad, Pakistan versus Tajikistan, the Indian subcontinent versus Russia), but also contributes to the embodiment of these differences which, in everyday life, reach into the domains of clothing, dance, musical tastes, and so on. These realms, including food, go beyond the symbolic representation of social bonds and divisions and actually 'participate in their creation and recreation'. ${ }^{101}$ Thus, even in meeting places beyond Karimabad and Khorog, the conditions of the divided borderlands continue to exert their particular influences on how people interact, locate themselves, and envisage the world beyond.

\section{Conclusion}

Paul Gilroy's work is the starting point for many debates on conviviality. In his 2004 book, After Empire, he seeks to counter post-9/1 1 racism and emerging nationalism with a utopian cosmopolitanism. ${ }^{102}$ Gilroy envisions a Britain in which the diversity that the empire has brought forth is embraced rather than ignored and neglected. Yet, in Gilroy's discussion, the spotlight is always on the

\footnotetext{
${ }^{100}$ Sutton, Remembrance of Repasts, p. 73.

${ }^{101}$ Ibid., p. 102.

${ }^{102}$ Gilroy, After Empire.
} 
imperial centre and the origins of those strangers who are located at the heart of the debate remain obscure and far-distant. In this context, the possibilities of a shared life are merely wishful thinking - a matter of hope and utopia. In this article, however, I have sought to explore what happens if we take the idea of 'convivial culture' to the fringes of different empires and political entities. The examples of Karimabad and Khorog, located at the very crossroads of historical British and Russian spheres of influence, highlight a series of points that might contribute to alternate understandings of the dynamics of life across difference.

The interaction between people who live in or feel connected to Khorog and Karimabad is determined by processes situated on different scales. In this regard, the idea of a micro-region uniting the border area of Afghanistan, China, Pakistan, and Tajikistan exists as part of a range of local scale-making projects. It serves to emphasize local belonging across modern frontiers and a distinct type of Ismailism. However, the historically more recent and salient trajectories are tied to imperial and national entities. At the same time, it is important to emphasize that these different scales are not necessarily contradictory and at odds with each other. James Scott's notion of the 'non-state spaces' that accompany such alternate scalemaking projects is only one side of the story. ${ }^{103}$ As the examples of Karimabad and Khorog demonstrate, instead of 'state evasion', we see manifold attempts to connect beyond national boundaries-yet with the nation state lingering, ever at the ready, amidst local and transnational identities.

Furthermore, throughout the article, I have argued that Karimabad's and Khorog's oscillation between centrality and marginality is informed by temporal and spatial regimes. I hope to have shown that marginality within the nation state is not the only dimension that matters in these places. Rather, like Anna Tsing, I have sought to look at marginality as a conceptual site and 'an analytic placement that makes evident both the constraining, oppressive quality of cultural exclusion and the creative potential of rearticulating, enlivening, and rearranging the very social categories that peripheralize a group's existence'. ${ }^{104}$ People in both Karimabad and Khorog have been subject to long-term projects of developmental modernism that are variously entangled with state interventions and

${ }^{103}$ Scott, The Art of Not Being Governed.

${ }^{104}$ A. L. Tsing, 'From the Margins' Cultural Anthropology 9(3), 1994, p. 279. 
ultimately shed light on reverse interplays of rural and urban areas. ${ }^{105}$ In this respect, the Soviet project and Ismaili endeavours reveal parallels, but they also constitute separating forces.

The politics of nostalgia that have emerged from these processes situate conviviality across the Wakhan divide in the past and in the future, yet ascribe to the present a merely fragmentary character. This is also linked to the unequally distributed capacities to connect. Despite local agency in many fields, a good share of the power to decide on the possibility of conviviality across the divide lies not in local hands, but in those of the political actors and development institutions that administer border and transport infrastructures, communication systems, mobility, and education. Political authorities, both local and acting from afar, as well as the figure of the Aga Khan IV and the overarching identity that global Ismaili institutions foster, are intricately entangled with this hierarchy of distribution. This is perhaps best exemplified by the fact that, in order to encounter a state of shared everyday life, a common language, and face-to-face interaction, people from Karimabad and Khorog seek institutionally regimented educational pathways that create spaces of encounter in distant places like London, removed from their own homes so close to one another and yet so far away.

${ }^{105}$ H. Jonsson, 'Above and Beyond: Zomia and the Ethnographic Challenge of/for Regional History' History and Anthropology 21 (2), 2010, pp. 191-2 12. 